\title{
THE DISSEMINATED INTERPRETATIONS OF HAJJ FROM DHU AL-NUN TO AL-SHIBLI AND THE PROBLEMS OF CONTEMPORARY PILGRIMAGE
}

\author{
Mohammad Anwar Syarifuddin \\ Syarif Hidayatullah State Islamic University (UIN) Jakarta \\ anwar.syarifuddin@uinjkt.ac.id
}

\begin{abstract}
This piece discloses a clear portrait of the Sufis' understanding on Hajj. The focus of our discussion will be on how Sufis correlate the detailed performance of Hajj to the hidden indications of its spiritual significances. Employing two distinctly disseminated interpretations of Hajj by way of reconstructing the mystical understandings of Dhu al-Nun (d. 245/861) and al-Shibli (d. 946), we can see the impacts of symbolic interpretations to the relevant forms of religious performances. Dhu al-Nun represents the proponent of Hajj of Islam once in a lifetime, whereas al-Shibli's mystical insight underlines the importance of the reprised sojourn that incites an escalating number of pilgrims during Hajj nowadays. The latter will cause problems for the limited capacity of the surrounding milieu at Mecca. To solve the problem, we must enroot the spirit of Hajj, as we have to go back to the ordinance of the Sharia. Dhu al-Nun had brilliantly shows the relevance of his symbolic interpretation signifying Hajj as a divine call that resembles the journey that man has to accomplish to return to God after death. Thus, the obligation of Hajj for a Muslim suffices once for a lifetime. Had it been reprised, the pilgrims would have barely felt the sweetness of mystical experiences during the hasty nasty Hajj nowadays, where congested Muslims were flooding the pilgrimage shrines.
\end{abstract}

Keywords: Sufi Qur'an commentary, Sufism, Hermeneutics, Anthropology of religion, cultural studies.

\section{Introduction}

From the perspective of Islamic law, we can define Hajj to mean performing pilgrimage to Mecca. Hajj is a combination of ritual exclusively fulfilled for God only, as seen from the interpretation of QS 2:196; 3:97 (Sulamī, 2001: i, 109), is performed using both sufficient expenses and physical stamina (Bayḍ̂āī 1999: ii, 69). Moreover, discourses on legal ordinances of the Sharia have been weighed by mystical perspectives rooted within the symbolic interpretations to the Qur'an, which are mainly found in the Sufi commentaries. In Sufi interpretations, God bestows the Sufis portions of His blessing by way of unveiling His direct knowledge that they perceived during their state of unveiling (mukāshafa). Accordingly, the interpretation is mystical in a sense that it is a sort of revelation guiding to reach spiritual significances, in addition to the formally textual meanings. Consequently, Sufis do not suffice to gain only the clear indications of the text without attempting to go beyond to reach a deeper understanding. As the mystical ideal is achieved, Sufism comes to draw a harmony between the Sharia and haquqa.

The Sharia is commonly perceived to be any theological underpinnings in all senses entitled to formal ordinances, whereas haqiqqa is attached to the ethical precepts lying beyond its formality. The purpose of the Sufi commentary is to unveil the spiritual significance of the Qur'an underlining the ethical quality of the ordinances. This piece is a further reading on the Sufi Qur'an interpretations previously discussed by P. Nwyia (1968, 1970, 1972), E. Kohlberg (1979), and G. Bowering (1991, 1995, 1996) on 
Sulamī's mystical interpretations. Besides, it deals with several junctions in between Sufism and the 'modern' as well as contemporary social issues in Martin Van Bruinessen \& J.D. Howell (2007) and Robert R. Bianchi (2013). However, this piece will particularly discuss only on the pilgrimage to get a clear portrait of the Sufis' understanding on Hajj. The focus of our discussion will be on how Sufis' hermeneutical procedures correlate detail performances of Hajj to hidden indications of the spiritual significances. Such findings are barely visible in general type of Qur'an commentaries but the Sufi ones. We provide several primary references here such as the Haqū'iq al-Tafsīr by Muhammad ibn 'Abd al-Raḥmān al-Sulamī, the Latā' if al-Ishārāt by 'Abd al-Karīm al-Qushayrī, and the Tafsīr al-Jìlanī by 'Abd al-Qādir b. Mūsa al-Jīlānī. In fact, al-Sulamī provided many symbolic interpretations of early Sufis, particularly the two dispersed interpretations on Hajj, from which we can reconstruct the juxtaposed commentaries of Dhu al-Nūn al-Mișrī (d.245/861) and Abū Bakr al-Shiblī (d. 334/946).

The two distinctly symbolic interpretations had disseminated not only within the framework of mystical thinking but also to the practices of Hajj in a broader perspective. Thus, we can correlate those findings to the quest of modern readers nowadays on how we take benefits from such mystical interpretations. We can utilize the interpretation to solve contemporary social problems, especially in addressing the lengthy lists of the registered performers of Hajj in so many regions in Indonesia, where they have to wait for about ten up to twenty years to go. Besides, what imbalances the limited capacity of the Grand Mosque as well as for the surrounding pilgrimage enshrines is the sweetness of experience felt during Hajj that caused certain pilgrims to perform their Hajj several times.

\section{Hajj as the Symbol of Journey after Death}

In addition to its legal ordinances, every session performed by the Sufis during pilgrimage can be paired with its spiritual states. In his Haqu' 'iq al-Tafsìr al-Sulamī gave an account originated from the authority of Dhu al-Nūn, the spiritual forebear of Sahl alTustarī (Bowering 1980: 55), who thoroughly comprise mystical significances behind the performance of Hajj. For him, pilgrimage to Mecca is associated with the Muslim's journey to heaven after his death. To mention Hajj as a divine call, Dhu al-Nūn put the performance of Hajj to a complex undertaking along the course of a human soul to return to Divine origin. In short, Dhu al-Nūn formulated the mystical significances of Hajj as sorts of vision of the spiritual states in the world to come (mushāhadāt aḥwāl al-äkhira). He put further the shared benefits of Hajj, i.e. to increase certainty about the witness of Hereafter, about the existence of spirit, leisure ( $r \bar{a} h \underline{h} a$ ), yearning to God, the need for intimacy within heart, tranquility to God, taking a lesson from the rituals, and to halt (wuqūf) on the mystical state of gnosis.

Formulating some symbolic interpretations of the details of Hajj, Dhu al-Nūn began with the symbol of the intent to Hajj that for him resembles the state of human beings in making their preparation to die. He said that the starting point of Hajj is by presenting firm intent ( 'azm) that resembles the feeling of the certainty of death, by which man will surely return to God. Accordingly, one is preparing to face his death by writing a testament (wasiyya), at the same time he gives many admonitions and looks after his devotional life to God in pursuit of Divine contention. In the state of getting out from the outrage slavery in all possible means, one will get out of the world like the deceased person being taken out from his dwelling in the world to move into his eternal abode in Hereafter. The journey he undergoes is very long; hence, he will have to ride his camel, by which the best ride is trust (tawakkul) carrying the best provision of righteousness (taqwā).

In fact, the journey is a trip to his burial ceremony. The state of getting into one's ride is associated as if he gets into the grave. The deceased's close associate is only his 
good deed ('amal șālih) along with the invocation (dhikr). To proclaim ihrām resembles the deceased being dispersed into the grave. The talbiyya that is loudly recited represents man's response to the Divine call (Sulamī, 2001: ii, 20-21). For Dhu al-Nūn sessions of rituals during Hajj are like the burial ceremony. Bathing ritual for $i$ hrām resembles washing the corpse. Clothes for ihräm resemble the white shroud. A halt at 'Arafât (wuqüf) resembles the event as the corpse is being taken to the grave, resurrected with soil on his head, and pushed by his leader. Marching following the leader is like the Prophet's intercession to his Lord when people are gathering around him to seek his advocacy. Muzdalifa resembles the passing through the path (sirāt), whereas the throwing (jumra) resembles the lifting of withdrawal: the received one will succeed and be rescued, but the rejected will face his bad fate. Al-Șafā and al-Marwa are like the two scales of a weighing machine. Al-Șafã is the good side, but al-Marwa is the bad side. During $s a$ ' $y$ one is running to reach both sides of the scales, waiting for which side is heavier. The place of sacrifice (mansak) is a high place (al-a $r \bar{a} f$ ) between Paradise and Hell. The Grand Mosque (alharām) is Paradise: one who enters it will be safe. The Ka'ba is the Throne of God. The circumambulation around the Ka'ba (tawaf) resembles the circumambulation of angels around Divine Throne. Shaving hair resembles notoriousness with the good deed (Sulami 2001: ii, 21). The shared context built by Dhu al-Nūn in between Hajj and its analogous conditions of man's death will occur only once in a lifetime. Some notable influences to such a mystical teaching are actually in parallel to the legal rulings of Sharia, by which classical Sufis like Sahl al-Tustarī and al-Hallāj also held the similarly mystical teaching of Hajj that has disseminated within the mainstream Islamic thinking. However, the later development of thought in Sufism, especially the Baghdadi mystical circles among the followers of al-Junayd, evoked a different symbolic interpretation to Hajj. They did not suffice a single Hajj for a lifetime as they formulated the reprised pilgrimage due to the sweetness of its spiritual experiences.

\section{Pleasant Experiences of Reprising the Sojourn}

An attempt to differently mold Hajj to some repeated sojourns is also visible in alSulamī's Haqū 'iq al-Tafsīr. The ingredients of such mystical teachings developed from alJunayd. In his admonition to someone departing for Hajj al-Junayd underlined the importance of tajrìd, a mystical term meaning "what is devoted exclusively to heart from the proof of Godhead, when it is pure from the dirt of humanity" (Qushayrī 1969: 49). In his mystical concept between the macrocosm of the ordinances and the microcosm of man's psychical states al-Junayd said that what is requested from one's performance during Hajj is that he is to take the Ka'ba (bayt Allāh) to be his heart, while the city of Mecca is its utmost part; and make the circumambulation around the $\mathrm{Ka}$ 'ba as a circumambulation with one's secret, in which he is to find God as he faces the Ka'ba. If not, he is considered to have already died (Sulamī, 2001: ii, 21)

A clear exposition of dialogue between al-Shiblī and one of his disciples among the proponents of the extended Baghdadi Sufis in Nishapur also underlines the richness of spiritual experiences during Hajj. As the dialogue continued after the person returning from his pilgrimage al-Shiblī verified that an intention to make Hajj resembles a contract to God, by which the pilgrim should annihilate any other violated to the agreement with God. In a mystical analogy, shedding clothes in white garment means to purify one's deed. Al-Shiblī explained further that purification entails the act of cleansing the entire impurities. Yelling the talbiyya is to bring to its response. Entering the sanctuary of al-harām implicates an agreement to get rid of all interdictions. Being close to Mecca confers divine honor to one's spiritual state. Entering the Grand Mosque is to begin closeness on the way of the gnostic state. Seeing Ka'ba is to meet the intended. To sprinkle sands in three times throwing and 
four times marching are to escape from the worldly danger, by which one who realizes to disconnects from the world finds his run safely from the eluded risk. As a result, he will increase his gratitude to God. Touching the black stone is like touching God, in which touching the stone will bring a feeling of being present in a safe place. Performing prayer afterward is like being in a halt in between the hands of God, a place to accomplish his intent. Running to al-Ṣafã is cleansing the secret (sirr) as one climbs up, and belittles the universe from his eyes as he is glorifying God. Hasten running during $s a^{\prime} y$ means a flee to God. Stopping by Marwa is to feel the descent of tranquility. Getting out to Mina is to give up his desire. Entering the dreadful mosque (masjid khayf) is to find out the increase of fear every time he gets into the mosque (Sulamī, 2001: i, 110-111).

Al-Shiblī continued that one's presence at 'Arafat is to add the gnostic state that one knows God and mutually God introduces him the way of the specialists. Getting through the mash 'ar by way of recollecting God to forget all remembrance other than Him, and upon which one palpates the way that God responses and converses. A sacrifice signifies annihilating desires and wishes in divine contention. Throwing is like obliteration of stupidity by the increase of understanding that purifies one's knowledge. Circumambulation signifies the unveiling in a gnostic state as a result of which one will gain the increasing marks of honor (karāmāt). Tahallul means an intention to eat only the Halal food. The farewell circumambulation is to get out from the self as well as spirit. At last, al-Shiblī concluded that anybody makes his Hajj outside the quality he had already described above is to reprise the ritual (Sulamī, 2001: i, 111-112.). Such a mystical interpretation has incited the Sufis to reprise their Hajj as it has no longer had been a lifetime obligation, but a series of joyful mystical experiences instead.

The Shifting Interpretations of Hajj from Dhu al-Nūn to al-Shiblī

\begin{tabular}{|c|c|c|c|}
\hline \multirow{2}{*}{\multicolumn{2}{|c|}{$\begin{array}{c}\text { Terms of Worship Rituals } \\
\text { during Hajj }\end{array}$}} & \multicolumn{2}{|c|}{ Symbolic interpretations } \\
\hline & & \multirow{2}{*}{\begin{tabular}{l}
\multicolumn{1}{c}{ Dhu al-Nūn } \\
A divine call: a journey to \\
heaven after death.
\end{tabular}} & \multirow{2}{*}{$\begin{array}{l}\text { al-Shiblī } \\
\text { A sojourn to face God in a } \\
\text { mystical path. }\end{array}$} \\
\hline Al-Hajj & $\begin{array}{l}\text { Pilgrimage to } \\
\text { Mecca }\end{array}$ & & \\
\hline Niyyat al-hajj & The intent to Hajj & To feel the certainty of death & A contract with God \\
\hline $\begin{array}{l}\text { Idzā balagha } \\
\text { mawdi'a al-iḥrām }\end{array}$ & $\begin{array}{l}\text { To arrive at the } \\
\text { point of ihrām. }\end{array}$ & $\begin{array}{l}\text { A deceased to enter the } \\
\text { grave being called upon in } \\
\text { between the hands of God. }\end{array}$ & To annihilate other than God. \\
\hline Talbiyya & $\begin{array}{l}\text { The response to the } \\
\text { divine call }\end{array}$ & $\begin{array}{l}\text { Fairness to himself, friends, } \\
\text { and trusty. }\end{array}$ & To bring a response. \\
\hline Ightisāl & Bathing for Iḥrām & Like cleansing the corpse. & To cleanse all impurities. \\
\hline Thiyāb & Clothes for iḥrām & $\begin{array}{l}\text { The white shroud wraps the } \\
\text { corpse. }\end{array}$ & To purify one's deed. \\
\hline Wuqū $f$ & Being halt at 'Arafa & $\begin{array}{l}\text { An event of a corpse is taken } \\
\text { to the grave. }\end{array}$ & Being in the state of knowing. \\
\hline Muzdalifa & $\begin{array}{l}\text { To come by } \\
\text { Muzdalifa. }\end{array}$ & $\begin{array}{l}\text { The passing way through the } \\
\text { Path (al-sirāt }) \text {. }\end{array}$ & To give up desire. \\
\hline Jumra & Throwing & $\begin{array}{l}\text { Lifting the withdrawal: the } \\
\text { received will attain success } \\
\text { and redemption; the rejected } \\
\text { will face his woeful fate. }\end{array}$ & $\begin{array}{l}\text { To disconnect from the world } \\
\text { and escaping from its danger; } \\
\text { obliterating stupidity by the } \\
\text { increase of understanding. }\end{array}$ \\
\hline
\end{tabular}


Table, Cont.

\begin{tabular}{|c|c|c|c|}
\hline \multirow{2}{*}{\multicolumn{2}{|c|}{$\begin{array}{c}\text { Terms of Worship Rituals } \\
\text { during Hajj }\end{array}$}} & \multicolumn{2}{|c|}{ Symbolic interpretations } \\
\hline & & \multirow{2}{*}{\begin{tabular}{l}
\multicolumn{1}{c}{ Dhu al-Nūn } \\
Two scales of weighing \\
machine: the goodness (al- \\
Șafā) and the badness (al- \\
Marwa); a man is waiting \\
for which side is heavier.
\end{tabular}} & \multirow{2}{*}{$\begin{array}{l}\text { al-Shiblī } \\
\text { Cleansing secret and belittling } \\
\text { the universe, fleeing with God } \\
\text { to feel the descent of } \\
\text { tranquility. }\end{array}$} \\
\hline $\begin{array}{l}\text { Sa'y bayn al-Ṣafā } \\
\text { wa al-Marwa }\end{array}$ & $\begin{array}{l}\text { Running back and } \\
\text { forth to the Safā } \\
\text { and Marwa. }\end{array}$ & & \\
\hline Mansak & $\begin{array}{l}\text { The place of } \\
\text { sacrifice }\end{array}$ & $\begin{array}{l}\text { The high spot in between } \\
\text { Paradise and Hell. }\end{array}$ & $\begin{array}{l}\text { Sacrifice: annihilation of } \\
\text { desire in divine contention. }\end{array}$ \\
\hline Al-Harāam & The Grand Mosque & $\begin{array}{l}\text { Paradise whom enters it will } \\
\text { be safe. }\end{array}$ & $\begin{array}{l}\text { To begin closeness by way of } \\
\text { knowing. }\end{array}$ \\
\hline \multirow[t]{2}{*}{$K a^{\prime} b a$} & \multirow{2}{*}{$\begin{array}{l}\text { The Ka'ba, } \\
\text { touching the black } \\
\text { stone. }\end{array}$} & \multirow[t]{2}{*}{ The Throne of God ('Arsh). } & To see the intended. \\
\hline & & & Touching God \\
\hline Tawā $f$ & $\begin{array}{l}\text { Circumambulating } \\
\text { around the Ka'ba }\end{array}$ & $\begin{array}{l}\text { The circumambulation of } \\
\text { angels around the Divine } \\
\text { Throne. }\end{array}$ & $\begin{array}{l}\text { The state of unveiling by } \\
\text { getting out completely from } \\
\text { the self and spirit. }\end{array}$ \\
\hline Tahallul & Shaving hairs & $\begin{array}{l}\text { Notoriety with the good } \\
\text { deed. }\end{array}$ & The intent to eat Halal food. \\
\hline
\end{tabular}

\section{Enrooting the Mystical Spirit of Hajj}

Along with the development of mystical thought in the middle ages, an increasing need to perform Hajj as a reprised journey can be read from several mystical sources. AlSulamī, for example, noted the promised benefits gained through Hajj like additions

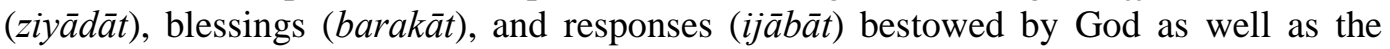
increase of devotional relationship between the worshipper and his Lord. Such a clear example is narrated in al-Sulamī's report on the performance of Hajj by a Nishapuri mystic Abū Sa ‘̄id Faḍl Allāh b. Abī al-Khayr al-Mayhānī (d. 440/1049). He began his Hajj in a unique way of announcing his intent to make $i \grave{r a} \bar{a} m$ from his departure from Nishapur. As a result, he performed two $\mathrm{raq}^{\text {' }} \mathrm{a}$ of prayer in every mile of his journey in between Nishapur and Mecca. Al-Sulamī concluded his report with a quote interpreting QS 22:28, "That they may witness benefits for them," as it was narrated from Abū Sa'īd, "Such is of the benefits I could derive in my pilgrimage." (Sulamī 2001: ii, 22).

The continuing trend of repeating pilgrimage is also implied in the later development of Sufism by 'Abd al-Qādir b. Mūsa al-Jīlānī (d. 561/1166), who classified two sorts of pilgrimage: the pilgrimage of Sharia and the pilgrimage of tariqa. The latter pilgrimage is accordingly an addition to its legal ordinance that is related to the mystical interpretation of QS 2:125, in which its inward meaning is to cleanse Ka'ba to have a vision to the Creator along with its analogous mystical states. Hence, the need to reprise Hajj is consequently to achieve perfection of the performance as the divine command in QS 2:196 is to complete the pilgrimage (see al-Jīlanī 1971: 45-46). Al-Jīlanī also underlined the resemblance of Hajj to the mystical purification of heart as he symbolized pilgrimage to be the death of desires. Accordingly, to perform Hajj is to obliterate one's natural self to win for the eternal life (al-Jīlanī 2010: i, 196). In short, spiritual benefits gained through the practice of Hajj have also improved the mystical lifestyle that does not only incite certain Sufis to reprise their Hajj, but a similar tradition also happens among the general populace. However, both Sufis and the laymen might have felt a different taste of joy as people might have to reprise their Hajj based on various purposes. Al-Qushayrī made a clear distinction in between the two that the essence of Hajj is the intent (al-qașd) to go. There is a distinction between the Hajj of the laymen whose aim is to go to see the house of God and that of the 
specialist among the Sufis, whose ultimate end is to see God (Qushayrī 1971: I, 175). However, the sequential series of worship rituals during Hajj can be paralleled in either Sufis or laymen as long as they keen to reprise Hajj regardless of their different purposes or intentions.

Nowadays, the escalating numbers of pilgrims during Hajj are in need of a fair treatment to balance the performance, by which reducing the quantity of pilgrim considering the limited capacity of the surrounding milieu at Mecca will certainly increase the quality of the ordained performance. Dhu al-Nūn had brilliantly put his symbolic interpretation that the divine call to Hajj resembles the journey that man has to accomplish to return to God after his demise. Thus, it suffices once only for a lifetime. Such is the core Islamic tenet that the mystical interpretation of Hajj is referred to the essential purpose of the ordinances of Sharia. Moreover, mystical experiences that call upon reprising Hajj as suggested by al-Shiblī in his symbolic interpretations might have barely been felt its sweetness by the pilgrims during the hasty nasty performance where the congested Muslims were flooding the Pilgrimage shrines. Thus, we need to enroot the performance of Hajj to the ordinance of Sharia, as Dhu al-Nūn had already attested its corresponding mystical understandings.

It will be fair that every Muslim is granted a chance to perform pilgrimage once in his/her lifetime, as anybody who keens to return may have been permitted to conduct a lesser pilgrimage, or 'Umra, at any time possible outside the cyclical pilgrimage season. However, such might have been reducing the mystical assessment to a lesser degree and quality, because 'Umra is without the distinctive halt (wuqūf) at 'Arafa. As we have shown above, 'Arafa plays a conspicuous role in Shibli's mystical understanding underlying the spiritual significance of Hajj as a means to achieve intimate proximity with God. By holding Dhu al-Nūn's mystical idea we have to be aware too of what Ja'far al-Ṣādiq underlined that Divine unveiling to human race could only occur under the state of obliterated humanness (khumūd al-bashariyya), hence an intimate vision of God cannot be reached in this world, but after the mystic dies.

\section{References}

Bayḍawī, 'Abd Allāh b. 'Umar, al- (1999). Tafsīr al-Bayḍ̄wī al-Musammā Anwār alTanzīl wa Asrār al-Ta'wīl. Beirut: Dār al-Kutub al-'Ilmiyya, 2 vols.

Bianchi, Robert R. (2013). Islamic Globalization, Pilgrimage, Capitalism, Democracy, and Diplomacy. Singapore: World Scientific.

Böwering, Gerhard (1980). The Mystical Vision of Existence in Classical Islam: The Qur'ānic Hermeneutics of the Șūfī Sahl at-Tustarī (d. 283/896). Berlin: de Gruyter. Studien zur Sprache, Geschichte und Kultur des Islamischen Orients, series no. 9.

Bowering, (1991). "The Qur'ān Commentary of al-Sulamī, in W.B. Hallaq and D.P. Little (Eds.), Islamic Studies Presented to Charles Adams, Leiden: E.J. Brill, 1991, pp. $41-56$.

Bowering (1995), The Minor Qur'ān commentary of Abū 'Abd al-Raḥmān Muhammad b. al-Husayn al-Sulami (d. 412/1021), Beirut: Librairie Orientale.

Bowering, (1996). "The Major Sources of Sulami’s Minor Qur'ān Commentary", in Oriens vol. 35, (1996), pp. 35-56.

Graham, T. (1999). "Abū Sa'īd ibn Abī al-Khayr and the School of Khurasān" in Leonard Lewisohn (ed.), Classical Persian Sufism from Its Origin to Rumī. Oxford: Oneworld, pp. 83-135.

Jīlānī, 'Abd al-Qādir b. Mūsā al-. (2010). Tafsīr al-Jīlān̄̄ (Ed. Ahmad Farīd al-Mazīdī). Kuwait: Maktabah al-Ma'rufiyya, 5 vols.

J̄̄lanī, (1971). Sirr al-Asrār wa Mažhar al-Anwār fìmā yahtāju ilayhi al-Abrār. (Ed. Ahmad 
Farīd al-Mazīēi. Beirut: Dār al-Kutub al-'Ilmiyya.

Kohlberg, E. (1979) "A Treatise on Sufism by Abū 'Abd al-Raḥmān al-Sulamī” in Jerusalem Studies in Arabic and Islam, vol. i, pp. 19-25 (intro.), Arabic text pp. 25-39.

Nwyia, P. (1972). Trois oeuvre inédites de mystique musulmans Šaqiq al-Balhi, Ibn 'Ațā', Niffari (ed. critique avec introd. par P. Nwyia). Beyrouth: Dar El- Machreq.

Nwyia, P. (1970). Exegese coranique et langage mystique: nouvel essai sur le lexique technique des mystiques musulmans. Beyrut: Dar el-Machreq, pp. 316-48.

Nwyia, P. (Ed.) (1968). "Sentences de Nūrī par Sulamī dans Haqā’iq al-Tafsīr" Melanges de l'University Saint-Joseph. Imprimerie Catholique, Appendice A, pp. 30-33.

Qushayrī, Abū al-Qāsim 'Abd al-Karīm b. Hawāzin al-, (1971). Lațā'if al-Ishārāât Tafsīr Șüfì Kāmil li al-Qur'ān al-Karìm (ed. with an introd. by Ibrahīm Basyūnī). Cairo: al-Hay'a al-Mișriyya al-'Āmma, 6 vols.

Qushayrī, (1969). Arba' Rasā'il fì al-Tașawwuf (ed. Qāsim al-Sāmarrā'î̀) Baghdad: alMajma' al-'Ilmī al-'Irāqī.

Sāmarrā'̄̄, Qāsim, al- (1968). The Theme of Ascension in Mystical Writings: a Study of the Theme in Islamic and non-Islamic Writings. Baghdad: National Printing and Publishing Co.

Subkī, Tāj al-Dīn al- (1964-76) Ṭabaqāt al-Shāfi 'iyya al-Kubrāa (Ed. Mạ̣mūd Muḥammad al-Ṭanāḥ̄ and 'Abd al-Fattāḥ Muḥammad al-Ḥuluw). Cairo: Isā al-Bābī al-Ḥalabī, 10 vols.

Sulamī, Abū 'Abd al-Raḥmān Muhammad b. al-Ḥusayn al-, (2001). Haqā'iq al-Tafsīr: Tafsìr al-Qur'ān al- 'Azīz (ed. Sayyid 'Imrān). Beirut: Dār al-Kutub al-'Ilmiyya, 2 vols.

Van Bruinessen, M. and Howell, J.D. (Eds.), (2007). Sufism and the 'Modern' in Islam. London: IB Tauris. 